\title{
Differences In Employee Productivity Koperasi Serba Usaha Tunas Mandiri Before And After Using The Financial Report Information System
}

\author{
Jermias Alang ${ }^{1}$, Amram Rohi Bire ${ }^{1}$ \\ \{jermiaskayalang@yahoo.com, amrambire386@gmail.com\} \\ Administration and Business Department, State Polytechnic of Kupang, Indonesia ${ }^{1}$
}

\begin{abstract}
The title of this research is "The Difference in Work Productivity Employees of Tunas Mandiri Multipurpose Cooperative Before and After Using the Financial Statement Information System in Kupang City. The Principal Problem Formulation of this Research is Is there a difference in the work productivity of the employees of the Kupang Tunas Mandiri Multipurpose Cooperative before and after the implementation of financial information systems? While the purpose of this study was to determine the differences in work productivity of the Tunas Mandiri Kupang Multipurpose Cooperative employees before and after the implementation of the financial information system. Methods of Data Analysis Techniques that are used the first test the research instrument (Validity) and Normality Test then parametric statistical test t-test (dependent sample test) using SPSS 16 application. The results show that the validity instrument test shows all instruments declared valid because it is greater than 0.30 and also the normality test shows that all data are normally distributed (the Sapiro-Wilk normality test). Based on the dependent sample test (t-test), it shows that there is a Difference in Employment Productivity of Tunas Mandiri Multipurpose Cooperative Employees Before and After Using the Financial Statement Information System. This is shown The Paired Sample Test shows the Sig. (2tailed) of $0.751>0.05$, shows there are differences in employee productivity before and after using the Financial Information System at KSU Tunas Mandiri Kupang.
\end{abstract}

Keywords: Difference, Productivity, Work, Employees.

\section{Introduction}

In today's digital era, the face of business competition, employees as natural resources are required to have more capabilities and abilities. In many companies, developing human resources to achieve its goals has become very important because the role of human resources in every company has a very important role for the company because humans are the main driving factor in carrying out company operations. The development of a company is very dependent on the good and bad of its human resources, therefore the implementation of human resource development must be done so that employees can improve their abilities and work skills, so they can carry out their work more productively. The rapid advancement of information technology in business management makes employee work productivity very competitive. As a result of the application of information technology in the company has made the position of human resources rich in function and poor structure so that there are savings in company operating costs. 
Koperasi Serba Usaha Tunas Mandiri Kupang in developing its human resources has conducted education and training for its employees to achieve work productivity. On the other hand, the development of employees' work capabilities is supported by the help of financial information system designs that have been carried out by researchers and colleagues on the previous year's research opportunities. This will certainly greatly encourage the work productivity of its employees. On this occasion, researchers need to conduct further research on the application of financial information systems that have been applied to find out whether there are differences in work productivity, employees in cooperative self-employed kupang independent businesses, before and after using the financial information system, have been able to increase employee productivity. The results of this study will determine whether or not the application is developed for other cooperatives in the city of Kupang.

The main problem in this study is there a difference in the work productivity of the employees of Koperasi Serba Usaha Kupang Tunas Mandiri before and after the implementation of the financial information system.

\section{Theory Review}

\subsection{Accounting Information System}

[1] suggests a general model for Accounting Information Systems consisting of; 1) Data Sources are various financial transactions that enter the information system from both internal and external sources. Financial transactions are a source of data. 2) Data Collection is the first operational stage in an information system. The aim is to ensure that the activity data that enters the system is valid, complete, and free of errors. 3) Data Processing, whereafter the data has been collected, data usually requires processing to produce information. 4) Database Management is a physical storage place for financial and non-financial data. 5) Information Making is the process of compiling, organizing, formatting and presenting information to users. 6) Feedback is a form of output that is sent back to the system as a data source.

Accounting system is a system that processes data and transactions to produce useful information for planning, controlling, and operating a business. To be able to produce the information needed by decision-makers, the accounting information system must carry out the following tasks; a) Gather transactions and other data and enter them into the system, b) Processing transaction data, c) Store data for future use, d) Generate the information needed by producing reports, or allowing users to see the data stored on their computers, e) Control the entire process in such a way that the information produced is accurate and can be trusted [4].

If related to the types of systems above, the accounting information system is a type of system that is relatively closed, because this system processes inputs into output by utilizing internal controls to limit environmental impacts. The input of an accounting information system is a transaction or economic event, for example, the sale of goods in cash the sale of goods on credit, payment of costs, and so on. These transactions are then processed by recording them in various reports. The output of the accounting information system is the financial report and management report. Figure 1 The following clarifies the understanding of accounting information systems as a relatively closed system. 


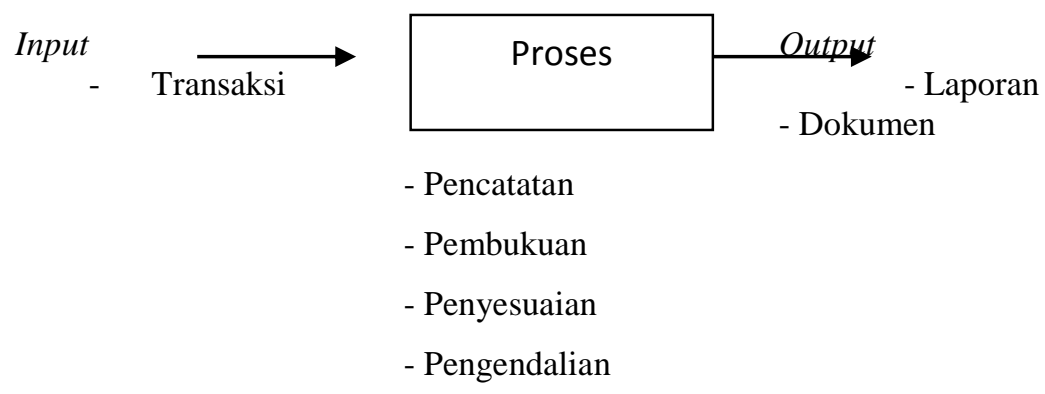

Fig 1. Accounting process as a relatively closed system

In accounting information systems, international supervision helps detect and prevent various environmental influences on the system. Examples of activities to reduce the influence of the environment are footing (sum of numbers in a column) and cross footing (comparison between column addition and row addition) [1].

\subsection{Work Productivity}

The nature of the measurement of work productivity in the form of the ratio between the products produced with the overall satisfaction that can be obtained with the sacrifice that has been given. Sulistiyani further explained the indicators of work productivity measurement as follows [7]:

a. Having the ability to carry out tasks and work is the ability of an employee to rely heavily on the skills possessed and the professional attitude of employees at work that provides power to complete the tasks carried.

b. Trying to improve the work achieved, results are one of the factors that can be felt both by those who work and who enjoy the results of the work.

c. The moral attitude is better than yesterday can be seen from the work ethic and the work achieved in one day later compared to the previous day.

d. Trying to develop themselves to behave better is to show the rhythm of work within the company in serving consumers.

e. Always developing themselves to improve work skills is to see the challenges and expectations with what they face.

f. Always trying to improve better quality is the result of work that can show good quality work of employees.

g. Comparison of the results achieved (output) with the overall input resources used.

h. Continually trying to improve the quality of life. The quality of a person's life is very dependent on the income/wages received during the employee's work and provides adequate work results so that employee welfare can improve.

\subsection{Indicators of Work Productivity}

Indicators of work, productivity includes [3]:

a. Quality of work

Is the implementation of work processes in designing work programs and be able to break down the problems faced so that the work will succeed in achieving the goals set. 
b. Work quantity

Is the amount produced or indicated in each measure by the number in units, the number of rounds or complete cycle of activities

c. Punctuality

Is the level of activity completed at the beginning of the stated time, viewed from coordination with output results and maximizing the time available for other activities.

d. Quality of work

The quality of work concerns the quality produced "an employee is required to prioritize quality in the implementation of his duties, quality for almost everyone seems to mean high quality.

The higher the quality, the better. Then the question arises whether people want everything of the highest quality possible. An employee as a resource that runs and carries out management in an organization must have a quality work life. Quality work life is a situation where employees can meet their needs by working within the organization.

e. Work quantity

Organizational development according to the quantity of work. The quantity of work involves the achievement of targets, the results of work under organizational plans. The ratio of the number of employees must be balanced with the quantity of work so that the balance can be a productive workforce to increase work productivity.

\section{Research Methods}

Data Analysis Techniques used first test the research instrument (Validity) and Normality Test then parametric statistical test t-test (dependent sample test) with the formula [1] :

$$
t=\frac{\delta}{\operatorname{SD} \delta / \sqrt{n}}
$$

Information :

$\delta=$ average deviation (the difference between sample before and sample after)

$\mathrm{SD} \delta=$ Standard deviation of $\delta$ (the difference between sample before and sample after)

$\mathrm{n}=$ number of samples

$\mathrm{DF}=\mathrm{n}-1$

This data analysis technique uses the help of SPSS 16 applications.

\section{Results And Discussion}

\subsection{Analysis Results}

Research Instrument Validity Test.

Judging from the validity test of 5 (five) statement items, all of them are valid, this is indicated by the Sig value for Employee Work Productivity before using the financial information system, respectively for the following; 
a) Validity Test Results

Before Using Financial Information Systems

\begin{tabular}{|c|c|c|c|c|}
\hline No Item & r-hitung & r-tabel 5\%(25) & Sig. & Kriteria \\
\hline 1 & 0.575 & 0,279 & .025 & Valid \\
\hline 2 & 0.824 & 0,279 & .000 & Valid \\
\hline 3 & 0.720 & 0,279 & .002 & Valid \\
\hline 4 & 0.866 & 0,279 & .000 & Valid \\
\hline 5 & 1 & 0,279 & .001 & Valid \\
\hline
\end{tabular}

b) Validity Test

After Using Financial Information Systems

\begin{tabular}{|c|c|c|c|c|}
\hline No Item & r-hitung & r-tabel 5\%(25) & Sig. & Kriteria \\
\hline 1 & 0.720 & 0,279 & .002 & Valid \\
\hline 2 & 0.824 & 0,279 & .000 & Valid \\
\hline 3 & 0.575 & 0,279 & .025 & Valid \\
\hline 4 & 0.866 & 0,279 & .000 & Valid \\
\hline 5 & 1 & 0,279 & .000 & Valid \\
\hline
\end{tabular}

Tests of Normality

\begin{tabular}{|l|r|r|r|r|r|r|}
\hline & \multicolumn{4}{|c|}{ Kolmogorov-Smirnov $^{\mathrm{a}}$} & \multicolumn{3}{|c|}{ Shapiro-Wilk } \\
\cline { 2 - 7 } & Statistic & \multicolumn{1}{c|}{$\mathrm{df}$} & \multicolumn{1}{c|}{ Sig. } & Statistic & \multicolumn{1}{c|}{$\mathrm{df}$} & \multicolumn{1}{c|}{ Sig. } \\
\hline Sebelum & .171 & 15 & $.200^{*}$ & .936 & 15 & .330 \\
Sesudah & .171 & 15 & $.200^{*}$ & .936 & 15 & .330 \\
\hline
\end{tabular}

a. Lilliefors Significance Correction

*. This is a lower bound of the true significance.

The results of Shapiro Wilk normality test show that the value of sig. Before using the Financial Information System of 0.330 where > from 0.05 and After 0.330 where > from 0.005 . This shows normally distributed data both before and after using the Financial Report Information System. 
c) Paired Sample Test

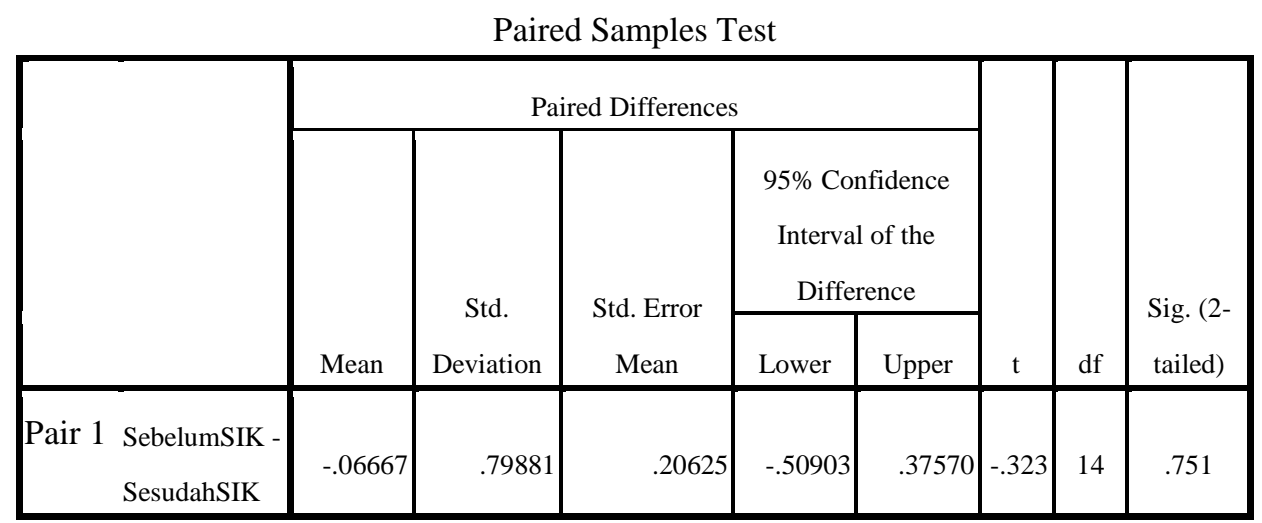

The Paired Sample Test shows the Sig. (2-tailed) of 0.751>0.05, this shows there are differences in employee productivity before and after using the Financial Information System at KSU. Tunas Mandiri Kupang. Thus from the results of this study, the Financial Information System applied to the KSU. Tunas Mandiri Kupang can be applied to other Multipurpose Cooperatives in Kupang City and surrounding areas so that the work productivity of its employees is more productive. The results of this study are also in line with previous research on the application of financial information systems to employee work productivity.

\section{Conclusion and Suggestion}

The results of the paired sample test analysis showed differences in employee productivity before and after using financial report information systems. Financial Information System applied at KSU. Tunas Mandiri Kupang can be applied to other Multipurpose Cooperatives in Kupang City and surrounding areas so that the work productivity of its employees is more productive.

From the results of research in which the Financial Information System can increase employee productivity, cooperatives or other business entities to increase employee productivity.

\section{References}

[1] Bahri : Pengaruh Penerapan Sistem Informasi Manajemen Terhadap Produktivitas Kerja Pegawai Pada Dinas Perhubungan, Komunikasi, Dan Informatika Kota Serang. Official URL: http://ane.fisip-untirta.ac.id/ (2018)

[2] Hasibuan. S.P. Malayu : Manajemen Sumber Daya Manusia.Jakarta :Bumi Aksara (2003)

[3] Krismiaji : Sistem Informasi Akuntansi, Penerbit ; Unit Penerbit danPercetakanSekolah Tinggi IlmuManajemenYKPN, Yogyakarta (2010)

[4] Mauliza : Pengaruh Sistem Informasi Manajemen terhadap Produktivitas Kerja Pegawai pada Kantor Pelayanan Pajak Pratama Medan Petisah.URL http://repository.usu.ac.id/handle/123456789/39420 
[5] Natalia : Pengaruh Peranan Sistem Informasi Manajemen Terhadap Produktifitas Kerja Karyawan Pada Bagian EDP (Electronic Data Procesing), sistem informasi manajemen berpengaruh signifikan terhadap produktivitas kerja karywan pada bagian transaksi pembayaran (Kasir) dan bagian EDP (Electronic Data Processing) https://openlibrary.telkomuniversity.ac.id/.../pengaruh-peranan-sistem-informasimana..

[6] Sulistiyani, Ambar Teguh : Memahami Good Governance Dalam Perspektif Sumber Daya Manusia. Yogyakarta : Gava Media (2004)

[7] Sugiono : Metode Penelitian Bisnis,Penerbit ; Alfabeta, Bandung. (2012) 